O. Volynets, postgraduate student of the State educational and scientific institution "Academy of Financial Management" of Kyiv

ORCID ID: 0000-0002-1188-3764

D. Bondarenko, postgraduate student of the State educational and scientific institution "Academy of Financial Management" of Kyiv

ORCID ID: 0000-0002-2802-2397

O. Hudenko, postgraduate student of the State educational and scientific institution "Academy of Financial Management" of Kyiv

ORCID ID: 0000-0002-5651-0371

B. Stakbov, postgraduate student of the National University of the State Fiscal Service of Ukraine ORCID ID: 0000-0002-5685-4932

\title{
FISCAL REGULATION OF SUSTAINABLE WATER USE: NATURAL RESOURCE AND DECENTRALIZATION CONTEXT
}

\section{О. Я. Волинець,}

аспірант, АННУ "Академія фінансового управління"

А. В. Бондаренко,

аспірант, АННУ "Академія фінансового управління"

О.А. Гуденко,

аспірант, АННУ "Академія фінансового управління"

Б. В. Стахов,

аспірант, Національний університет державної фіскальної служби Украӥни

ФІСКААЬНЕ РЕГУЛЮВАННЯ СТАЛОГО ВОАОКОРИСТУВАННЯ: ПРИРОАНО-РЕСУРСНИЙ ТААЕЦЕНТРААІЗАЦІЙНИЙ КОНТЕКСТ

It has been proved that the main form of charge of natural rent in the conditions of reforming local selfgovernment and territorial organization of power is the collection of rent for special water use from surface underground sources. It is reasonable that one of the instruments to promote the sustainable use of water and simultaneously a regulator of the formation of the water rent and water "anti-rent" (in case of pollution by the wastewater of water bodies) is an environmental tax for discharges of pollutants directly into water bodies. It has been determined that the key effective indicator of the budgetary decentralization reform is the distribution of water rent, including the fee for special use of water from water bodies of national importance between the state and local budgets equally, that is, fifty-fifty, which, on the one hand, has expanded the tax base of pumping up the local budgets, and on the other - has increased the interest of local government to ensuring adequate and transparent charge of water rent based on the volume of water resources attracted in circulation from the natural resource sphere. It has been established that the non-consideration of the sectoral and reproductive characteristics of the economic development of water resources potential has led to significant excesses and imbalances in the formation and charge of water rent in various segments of the national economy, in particular in the natural resource sector. Studies have shown that positive changes in the dynamics of the nominal value of the water rent are related to the influence of quantitative factors (revision of the payment standards due to the inflation processes) and not to the influence of qualitative changes in terms of expanding the tax base for this fiscal payments, forming disincentive inertial effects of fiscal regulation of sustainable water use of the natural resource sector of the national economy in the context of decentralization. 


\section{ЕКОНОМІЧНА НАУКА}

Доведено, що основною формою вилучення природної ренти в умовах реформування місцевого самоврядування й територіальної організації влади є стягнення рентної плати за спеціальне використання води 3 поверхневих із підземних, жерел. Обгрунтовано, що одним з інструментів Стимулювання Сталого використання води й водночас регулятором утворення водної ренти і водної "антиренти" (за умов забрУАнення зворотними водами водних об'єктів) є екологічний податок за СКиди ЗабрУАнюючих речовин безпосередньо У водні об'єкти. Визначено, що кАючовим результативним індикатором реформи бюджетної,децентралізації є вилучення й розподіл водної ренти в тому числі збору за спеціальне використання води з водних об'єктів загальнодержавного значення між, державним та місцевими бюджетами порівну, тобто П'ятдесят на п'ятдесят, що, з однієї сторони, розширило податковУ базУ наповнення місцевих бюджетів, а з іншої - підвищило інтерес місцевого самоврядування до забезпечення адекватного й прозорого вилучення водної ренти, виходячи з обсягів залучення водних ресурсів в обіг у природно-ресурсній сфері. Встановлено, що неврахування галузевих та відтворювальних характеристик господарського освоєння водно-ресурсного потенціалу призвело до значних перегинів і дисбалансів в утворенні та вилученні водної ренти в різноманітних сегментах національної економіки, зокрема в природно-ресурсному секторі. Дослідження показали, що позитивні зрушення в динаміці номінальної величини водної ренти пов' 'зані із впливом кількісних чинників (перегляд нормативів плати у зв 'язку з інфляційними процесами), а не під вПливом якісних зрушень у частині розширення податкової бази Стягнення цього виду фіскальних платежів, формуючи дестимуляційні інерційні ефекти фіскального регулювання Сталого водокористування природно-ресурсного сектору національної економіки в умовахдецентралізації.

Key words: water resources, rent, decentralization, environmental tax, sustainable development.

Ключові слова: водні ресурси, рента, дечентралізачія, екологічний податок, сталии розвиток.

\section{STATEMENT OF THE PROBLEM IN GENERAL AND ITS CONNECTION WITH IMPORTANT SCIENTIFIC OR PRACTICAL TASKS}

The increase in tariffs for the supply of cold and hot water follows from the currently dominant trend of the rise in the price of services of natural resource monopolies. At the same time, the paradigm rule for determining the adequate real value of the price for the use of water resources takes into account the value of water rent, which is formed in the process of economic development of water and resource potential.

The form of charge of natural rent in the current conditions is the collection of rent for special water use from both surface and underground sources. This fiscal payment is aimed to charge from the water user that part of the rent, which is formed under the influence of natural factors and is partially related to the reimbursement of materialized costs incurred in the past and aimed at the creation and development of water infrastructure facilities. The deepening of the decentralisation processes puts new demands on the rent regulation system since the solution of water management problems requires the formation of special funds, the main source of which is the rent for special use. Methodological approaches to the collection of environmental tax for the emission of pollutants are also insufficiently justified, as they do not provide adequate incentives for water users to minimize the negative impact on natural water bodies.

\section{ANALYSIS OF RECENT STUDIES}

Such economists as O.M. Alymov, A.I. Amosha, O. Baranovsky, B.V. Burkynsky, S.S. Hasanov, V.M. Geets, A.A. Grytsenko, T.I. Yefymenko, D.F. Krysanov, V.V. Mykytenko, S.V. Petrukha, A.M. Sokolovskaya, N.M. Sheludko, O.M. Shubaly, S.S. Shumska and others studied the methodological support of fiscal and tax sustainable development of economic systems at macro-, meso - and microeconomic levels, including natural resource and agricultural sectors of the economy. Problems and prospects of regulatory and institutional support for the reproduction of natural resource capital, as well as promising directions for improving the fiscal stimulation system of sustainable water use, are considered in the works of I. K. Bystryakov, O.O. Veklych, Y.S. Vytvytsky, V.A. Golyan, V.A. Dukhovny, J.M. Dorosh, V.M. Zhuk, S.I. Ibatullin, V.I. Kutsenko, L.V. Levkovska, A.V. Stepanenko, A.M. Sunduk, M.A. Khvesyk, etc. Normative legal support and organization of guidance documents in the field of sustainable water use in the conditions of reforming local self-government and territorial organization of power were investigated by V.B. Averyanov, S.S. Alekseev, O.M. Bandurka, V.M. Bevzenko, Y.P. Bytiak, Z.S. Hladun, R.A. Kaliuzhny, O.V. Kuzmenko, O.M. Iakuba et al. Despite the high level of research, the approaches regarding the deepening of differentiation of standards of payment for special water use and environmental tax rates for emission of the pollutants into water bodies, which would take into account the progress achieved in the decentralization reform and be consistent with the best international practices in this area need additional reasoning. The formation of modern tools of accumulation of state and local funds for the development of water resources, the main sources of formation of which is the rent for special water use, their balancing with the national sustainable development goals, which are formed on the basis of the Sustainable Development goals of the UN until 2030 is a challenging issue at present.

\section{PURPOSE OF THE ARTICLE}

The purpose of the article is to assess the main trends in the revenues of the main components of the rent for the special water use to the state and local budgets, as well as to substantiate the directions of increasing the efficiency of tax regulation of water use to stabilize and form the indicators of sustainable water use in the natural resource and agricultural sectors of the national economy against the background of the reform of local government and territorial organization of power.

\section{PRESENTATION OF THE MAIN MATERIAL}

For many years, the rent for special use of water, and until recently, the fee for special water use, is charged on the basis of the basin and territorial principle. The rental rates are differentiated by major river basins for surface 






The rental fee for special water use (excluding the rental fee for special use of water of local water bodies), min. (left axis)

The rental fee for special water use (excluding the rental fee for special use of water uf lowal water loulies) in comparative prices of 2002, mln. (left axis)

$=\bullet$ Specific weight of rent for special water use (except for the rent for special use of water of local importance) in the total volume of receipt of rent for special use of water in the consolidated budget of Ukraine, \%

Fig. 1. The dynamics of rent payment for special use of water to the consolidated budget of Ukraine

Reference: [9-12; 15].

sources and by administrative regions and districts for the underground ones $[1-3 ; 16]$. At the same time, the role of water resources in economic turnover is not taken into account. That is, whether water acts as a means of production, the material basis for the finished product, the provisional remedy of the production process or the final product. In particular, water is a means of production in fisheries and irrigation agriculture, a material substance of the finished product in food production, a provisional remedy in beet-sugar production, a final product in the municipal water supply and in the bottled water market [15].

The non-consideration of the sectoral and reproductive characteristics of the economic development of water resources potential has led to significant excesses and imbalances in the formation and charge of water rent in various segments of the national economy. Therefore, we have a situation when water rent is almost completely appropriated by the water user and is one of the main reasons for obtaining super-profits (bottled water market [14]), and in others the excessive amount of rent for special water use reduces the competitiveness of final products (agricultural production on the basis of irrigated agriculture $[13 ; 15])$.

Partial solution to the problem of equitable charge of water rent and thus overcome sectoral imbalances in the collection of rent for special use of water would be a complement to the territorial and basin principle of establishment of the payment rates by the correction coefficient associated with the profitability level of final products and the provision of services (this applies primarily to those activities where water is the final product, in particular, the bottled water market [14-15]).

In the period from 2003 to 2018, the upward trend (2003-2013) and the descending one (2014-2015) were observed in the dynamics of the nominal value of rent for the special use of water (up to 2015, the fee for special water use). The annual increase in the amount of rental payments for special use of water is associated with the indexation of payment standards due to the inflation processes. In particular, in 2013, the amount of rent fee for special use of water to the consolidated budget of Ukraine increased by 5.2 times compared to 2003 and by 2.3 times compared to 2008 (fig. 1).

The decrease in water rent revenues in 2014 and 2015 is due to the fact that the volume of special water use in the annexed Crimea and the occupied territories of Donetsk and Luhansk regions were withdrawn from the tax base within the legal framework of Ukraine (traditionally, in the last two regions, the volumes of special water use were significant due to the high proportion of water-intensive production in the structure of regional business complexes).

The amount of water rent transferred to the consolidated budget of Ukraine decreased by UAH $147 \mathrm{mi}-$ llion in 2015 compared to 2013 , and the volume of water rent revenues to the budgets of all levels increased by $232 \mathrm{mi}-$ llion UAH in 2016 compared to 2015. Positive changes in the dynamics of the nominal value of water rent received in 2018 , associated with the influence of quantitative factors (revision of payment standards due to inflation processes) and not under the influence of qualitative changes in the expansion of the tax base of this type of fiscal payments (as evidenced by the decrease in revenues in 2018 from the rent for special water use in the consolidated budget of Ukraine in prices of 2002).

In general, in 2018, the revenue of the rent from special water use in comparable prices of 2002 to the budgets of all levels is the lowest indicator for the analyzed period. That is, the fiscal return of the collected water and, accordingly, the real amount of water rent, which is withdrawn to the budgets of all levels, are reduced. In particular, the real amount of rent for special water use, which was transferred to the consolidated budget of Ukraine, decreased by 56 million UAH in 2016 compared to 2003, by 53 million UAH in comparison with 2008, and by 137 million UAH in comparison with 2013. For the period from 2003 to 2018 , the proportion of rental fee for special water use (excluding the rental fee for special water use of water bodies of local importance) in the total receipts for water rents in the consolidated budget of Ukraine ranged from 70.5 to $83.1 \%$. 


\section{ЕКОНОМIЧНА НАУКА}

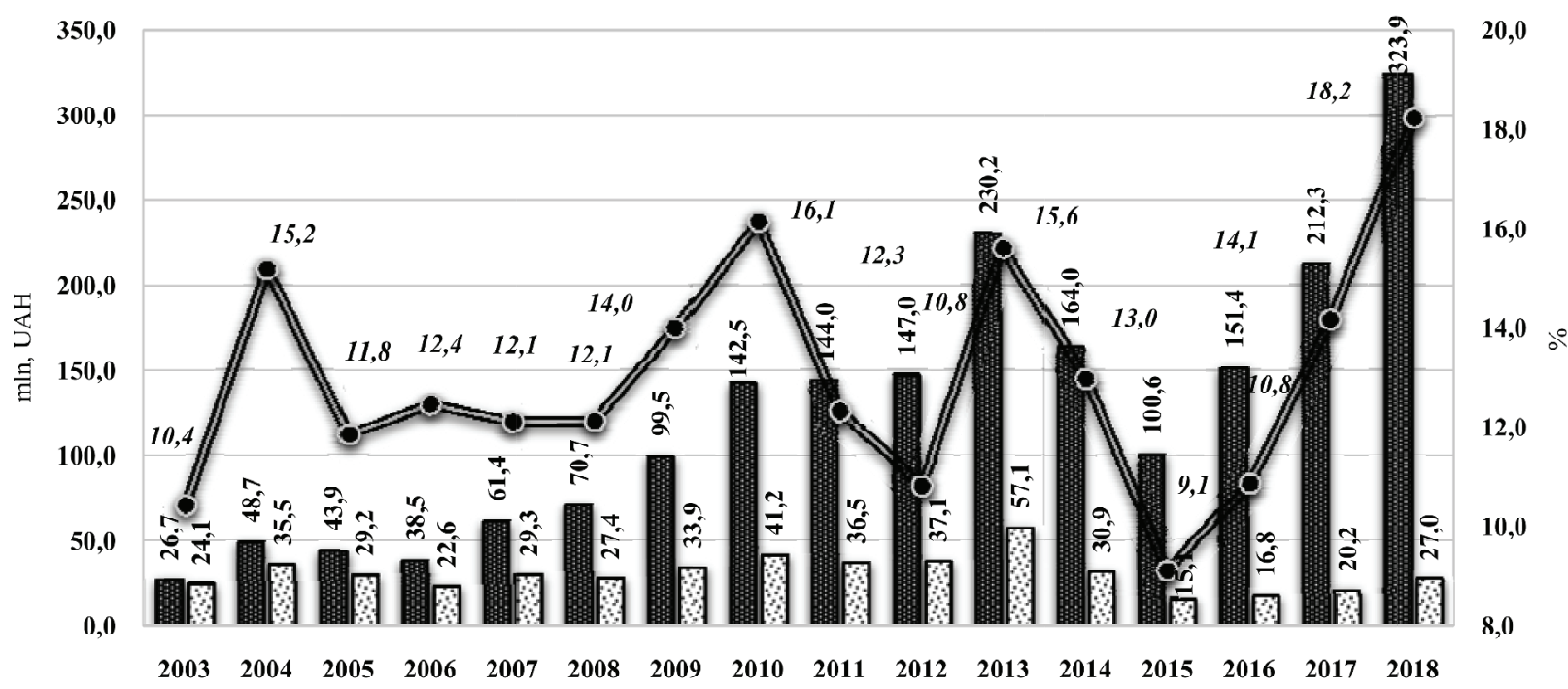

Fip; Rent for special use of water for the needs of hydropower and water transport, million UAH. (left axis)

Rent for special usc of water for the necds of hydropower and water transport, in comparable prices of 2002, million UAH. (Icft axis)

- - The share of rent for special use of water for the needs of hydropower and water transport in the total amount of the rent for special use of water in the consolidated budget of Ukraine, \% (right axis)

Fig. 2. The dynamics of rent payment for special water use for the needs of hydropower and water transport to the consolidated budget of Ukraine

Reference: [9-12; 15].

Based on the structure of the national economy, in particular, its energy sector, a significant component of the charge of water rent is the identification of the base and forms of methods of charging rent for special water use for the needs of hydropower and water transport. An upward trend was prevailing in the dynamics of the revenues of this component of water rent to the consolidated budget of Ukraine in the period from 2003 to 2018, except for 2006, 2014,2015 (fig. 2). Thus, the volume of revenues of the rent for special water use for the needs of hydropower and water transport increased by 203.6 million UAH in 2013 compared with 2003 , and by 159.5 million UAH in comparison with
2008. The decrease in the revenues of this component of the water rent is due to the fact that part of the territory of Ukraine has been occupied and annexed. The nominal amount of rent for special water use increased by $223.3 \mathrm{mi}-$ llion UAH in 2018 compared to 2015.

An upward trend is prevailing in the dynamics of rent for special use of water for hydropower and water transport in comparable prices of 2002 in some periods of the analyzed time horizon (from 2006 to 2013 and 2018). There was a significant reduction in revenues of rent for special use of water for hydropower and water transport calculated in comparable prices of 2002 between 2014 and 2017. The share



Fig. 3. The dynamics of rent payment for special water use from the housing and communal enterprises to the consolidated budget of Ukraine

Reference: [9-12; 15]. 


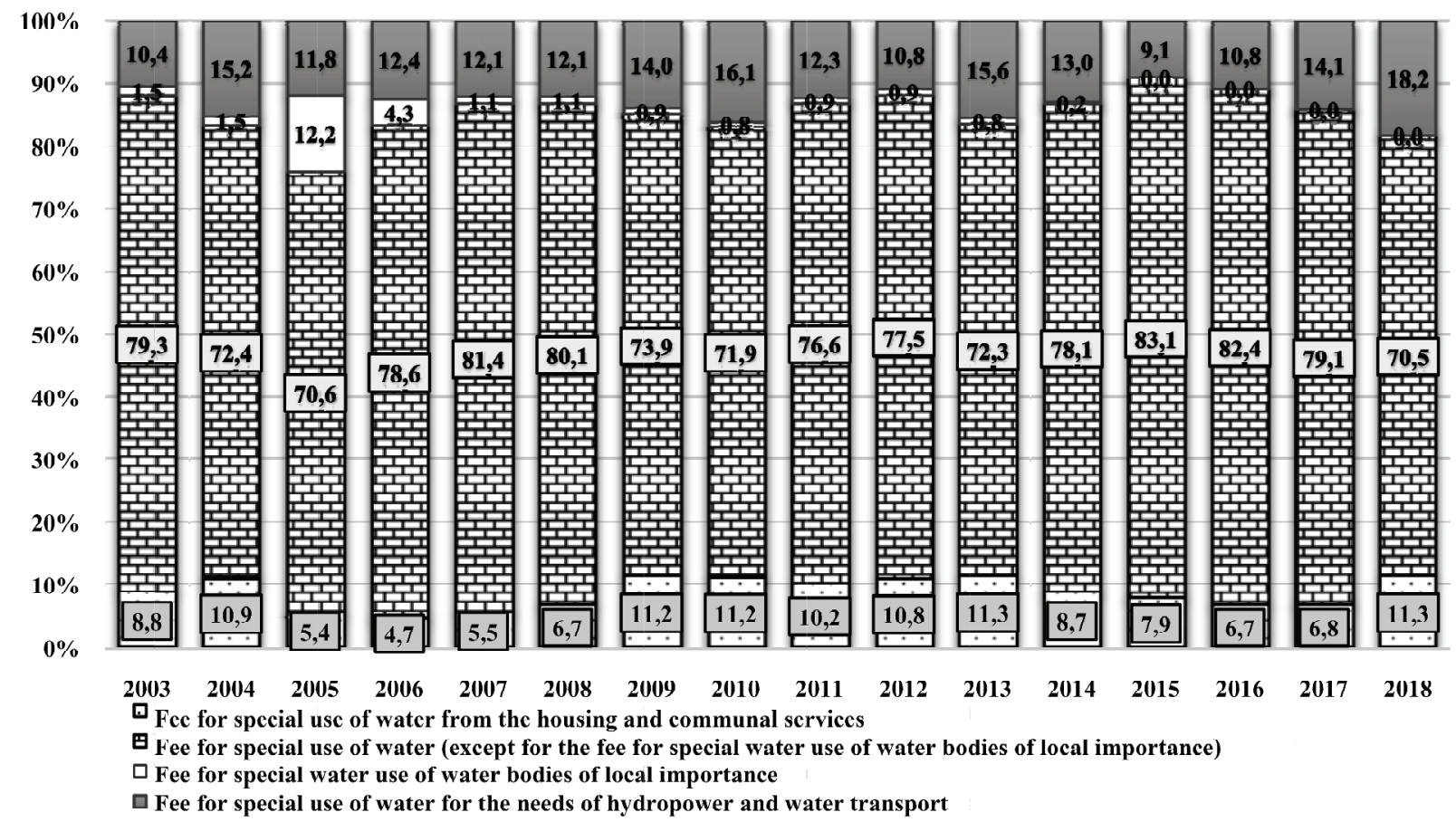

Fig. 4. The dynamics of rent payment for special use of water to the consolidated budget of Ukraine

Reference: [9-12; 15].

of this component of the water rent over the period between 2003 and 2017 ranged from 9.1 to $14.1 \%$.

Based on the significant volume of attracting "fresh" water for the needs of housing and communal services, a separate code of budget classification is allocated - the receipt of rent for special water use from housing and communal services. There was an annual growth of this type of revenues to the consolidated budget of Ukraine from 2003 till 2018. In particular, this component of water rent increased by 7.3 times in 2013 compared to 2003 and by 4.2 times compared to 2008 (Fig. 3).
There was a significant decrease in the nominal amount of rental fee for special water use from the housing and communal services in the consolidated budget of Ukraine in 2014 and between 2016 and 2017. The receipt of this payment decreased by 72.9 million UAH in 2016 compared to 2013. Again, the main reason for this rapid decrease in revenues from this component of water rent to the consolidated budget of Ukraine is associated with the occupation and annexation of part of the territories of Ukraine. A significant reduction in the actual revenues of rent for special water use from the housing and communal

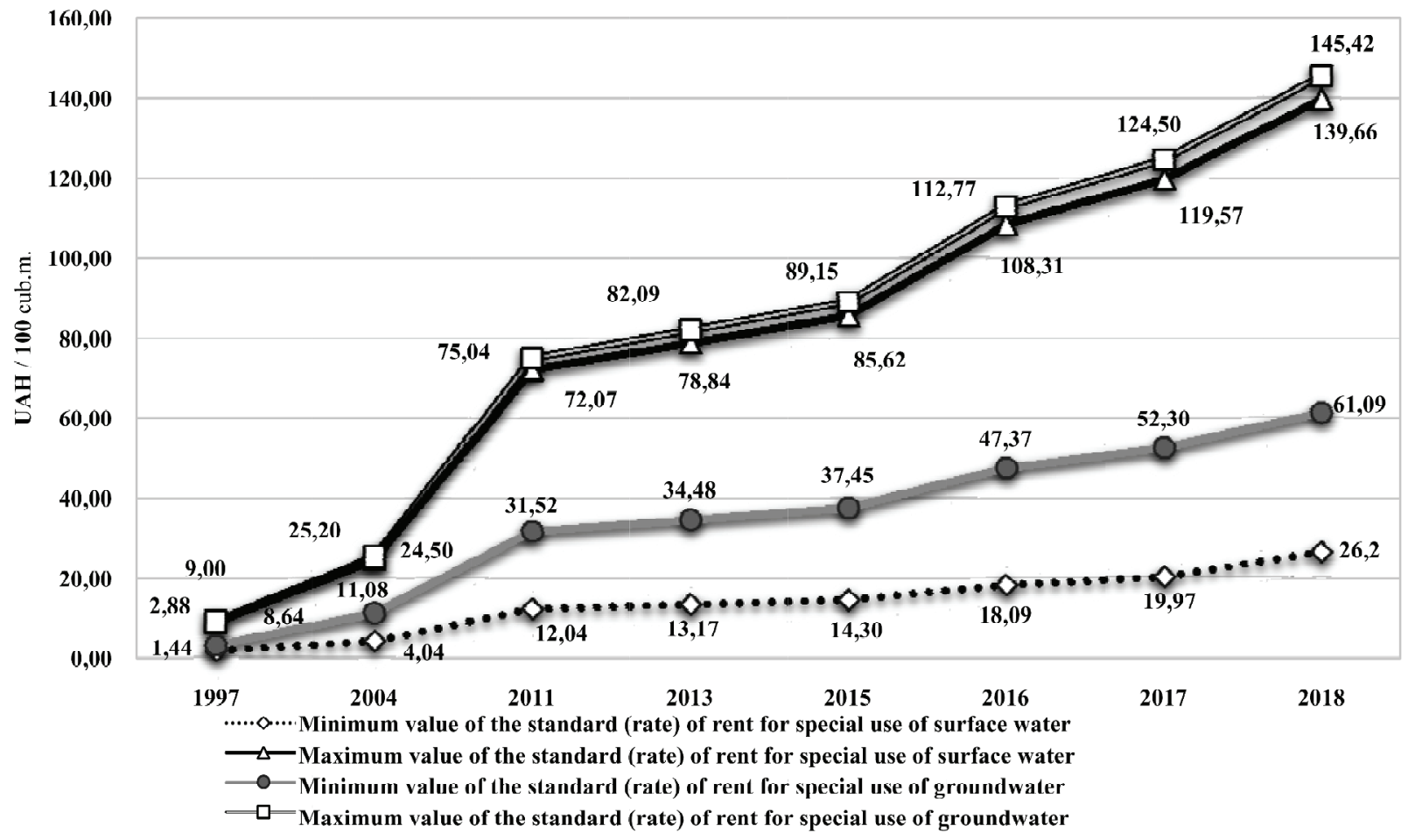

Fig. 5. Dynamics of payment rates for special use of surface and underground waters

Reference: [9-12; 15]. 


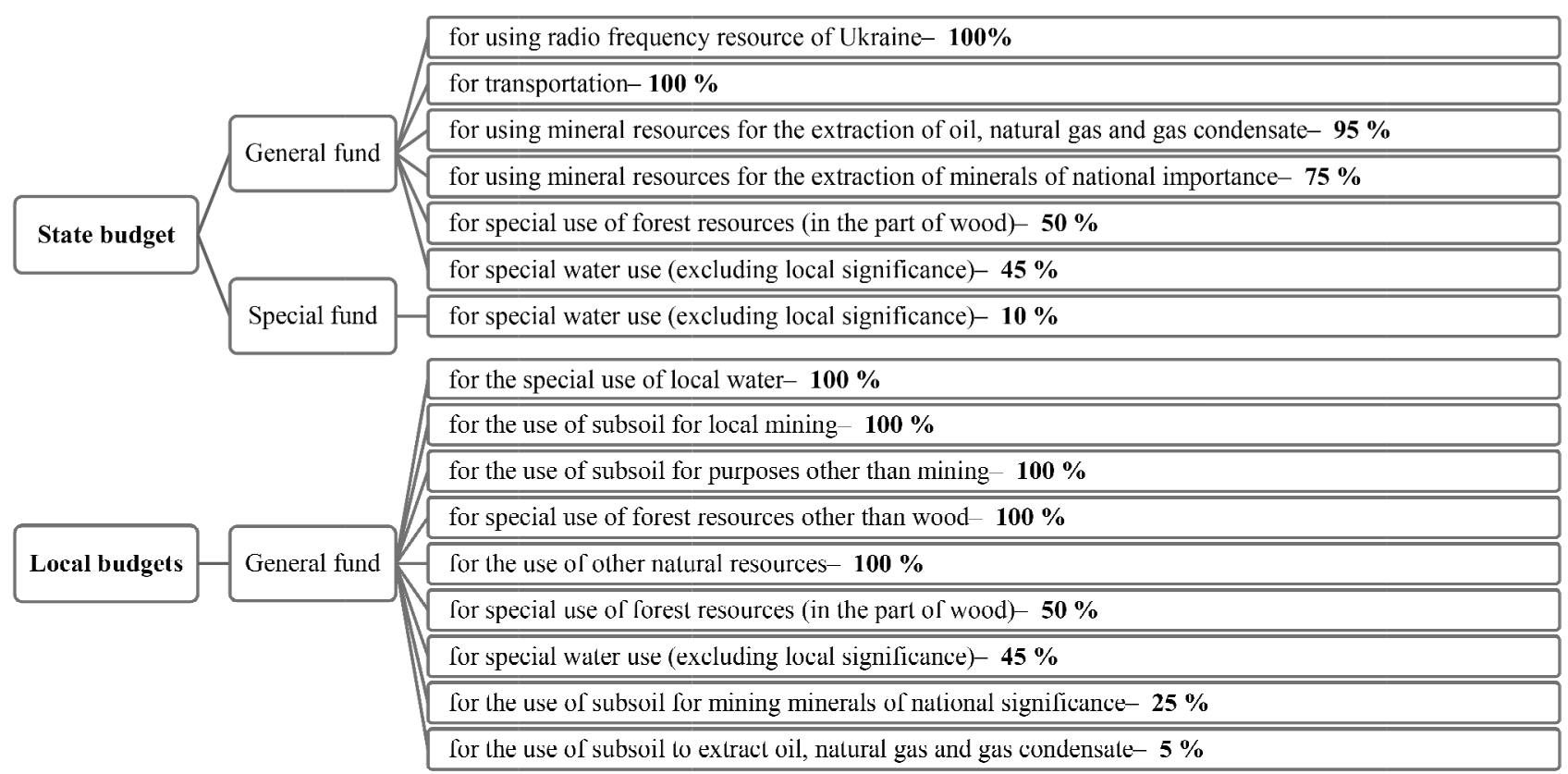

Fig. 6. The new architecture of the system of rent distribution between public and local budgets

Reference: [8].

services in the consolidated budget of Ukraine between 2014 and 2016 was reflected in the amount of this payment in comparable prices of 2002. The receipt of rent for special water use from the housing and communal enterprises in the consolidated budget of Ukraine decreased four times in 2016 compared to 2013, and there was a trend towards its growth in 2018, as the indicator approached the values of 2014. According to the information $[5 ; 7-8]$, between 2003 and 2018, the share of rent for special water use from the housing and communal services in the total volume of water rent in the consolidated budget of Ukraine ranged from 4.7 to $11.3 \%$.

A distinctive feature of the dynamics of this indicator is that its decrease has been generally observed since 2009 . This indicates that the growth of the rent rate for special



Fig. 7. The dynamics of rent payment for special use of water to the state budget of Ukraine water use from housing and communal services is slackening compared to the increase in revenues of other components of water rent.

There were some changes in the structure of rent for special water use coming to the consolidated budget of Ukraine in 2018 compared to 2003, in particular, the share of:

rental fee for special water use (except the rent for special water use of local water bodies; the fee for special water use of national importance was established in 2003) decreased from 79.3 to $70.5 \%$;

rental fee for special water use increased in $2018 \mathrm{com}$ pared to 2013 by $7.8 \%$ (the fee for special water use for hydropower and water transport was collected for 2003) to $18.2 \%$

.

Reference: [9-12; 15]. 




\footnotetext{
ZRent for special use of water received by the local budgets of Ukraine, million UAH. (left axis)

Rent for spccial usc of watcr reccived by the local budget of Ukrainc in comparison prices of 2006, million UAH. (left axis)

The share of rent for special use of water received by the local budgets of Ukraine in the total amount of rent for the use of

---- water in the consolidated budget of Ukraine, \% (right axis)
}

Fig. 8. The dynamics of rent payment for special use of water to the local budget of Ukraine

Reference: [9-11; 15].

rent for special water use from housing and communal increased in 2018 compared to 2015 , is due to the fact that services in 2018 compared to 2003 increased from $2.5 \%$ to $11.3 \%$.

A distinctive feature of the fiscal regulation of special water use is that the share of rent for special water use of local water bodies decreased from $1.5 \%$ to zero percent (fig. 4) in 2018, compared to 2003.

A significant decrease in revenues of rent for special water use in 2018 compared to 2003 and the failure to achieve even the value of 2005 (the lowest value in the audit period), despite the fact that, the rental rate significantly the part of the annexed and occupied territory of Ukraine was withdrawn from the tax base.

If on January 1,2015, the rent rate for the special use of surface water ranged from 14.3 to $85.62 \mathrm{UAH} / 100$ cubic meters, then on January 1,2018 , it ranged from 26.2 to 139.66UAH / 100 cubic meters. The lowest rent rate for special water use was traditionally in the Danube river basin, and the highest one - in the basin of the Azov rivers. The rent rate for special water ranged from 37.45 to $89.15 \mathrm{UAH}$ $/ 100$ cubic meters as of January 1,2015 , and from 61.09 to

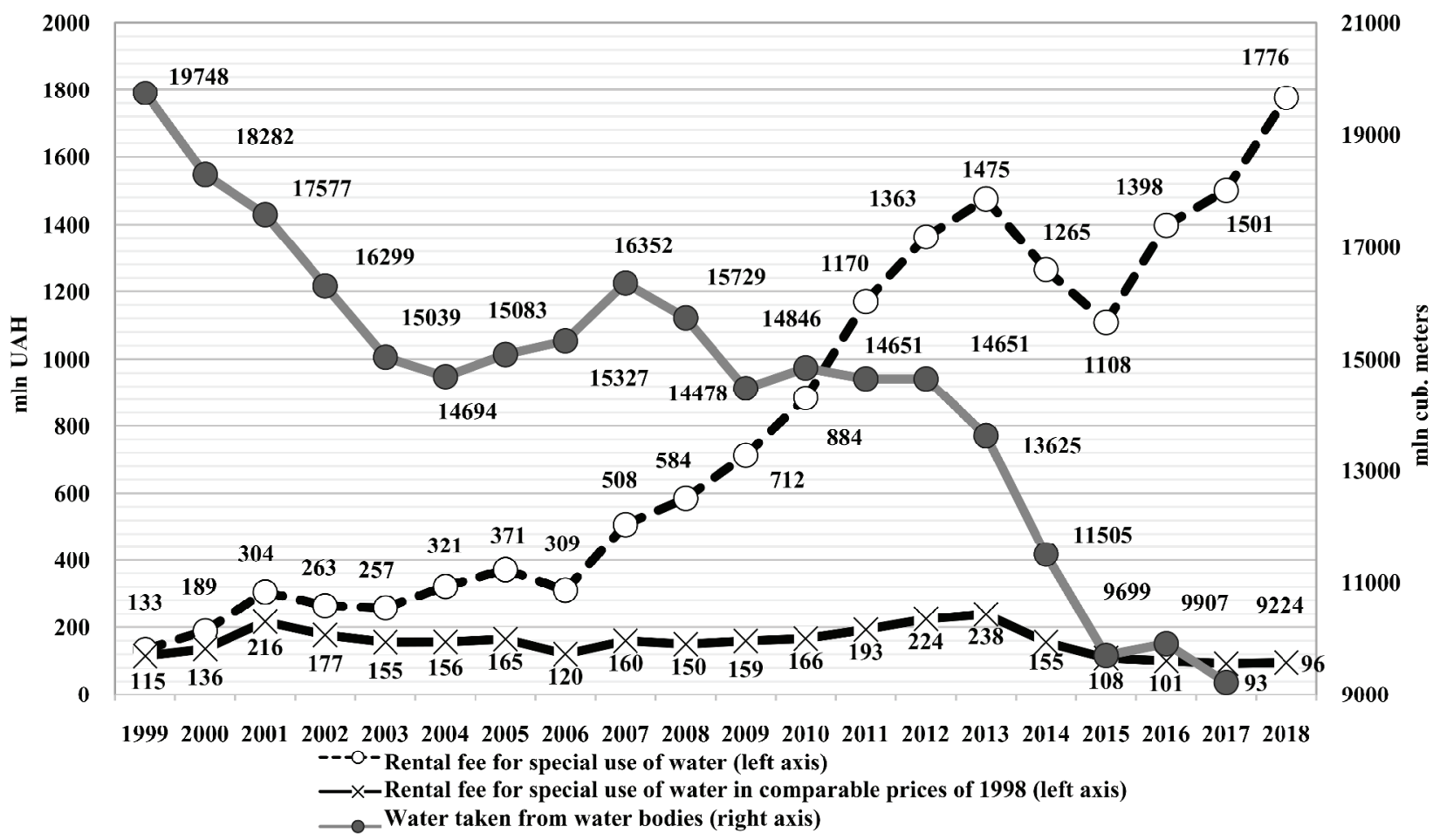

Fig. 9. The dynamics of water collection from water bodies and rent (fee) for special use of water Reference: [9-11; 15]. 


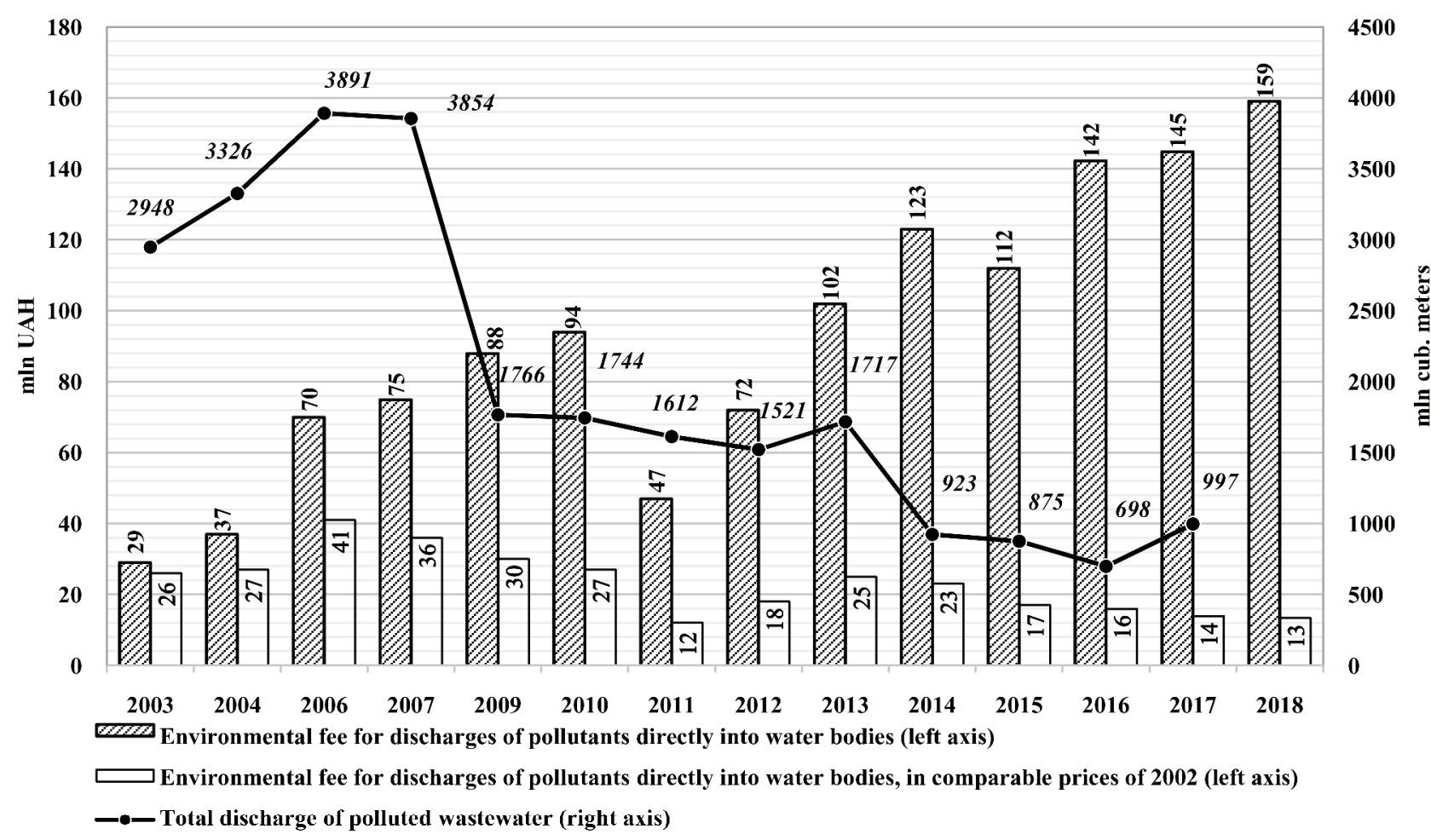

Fig. 10. Comparison of the environmental fee for the discharges of pollutants directly into the water bodies with the total discharge of polluted wastewater

Reference: [9-11; 15].

145.42 / 100 cubic meters as of January 1,2018 . The highest rent rates for special use of groundwater were in some administrative areas of Ivano-Frankivsk, and the lowest in Zakarpattia region (fig. 5).

The trend towards a mechanical increase in the rental rates for special use of water remained in 2019 [11-12]:

1) surface water: Dnipro to the north of Kyiv (Pripyat and Desna), including Kyiv - 58.17 UAH for 100 cubic meters; Dnipro to the south of Kyiv (without Ingulets) 55.33; Ingulets - 84.39; Siversky Donets - 113.45; Pivdenny Buh (without Ingulets) - 63.97; Ingulets - 78.49; Dniester - 34.85; Visla and Zahidny Buh - 34.85; Prut and Siret 26.17; Tysa - 26.17; Danube - 23.32; Crimea rivers 116.32; Azov rivers - 139.66; other water bodies - 63.97;

2) groundwater: the Autonomous Republic of Crimea (without Sevastopol) - 107.58 UAH per 100 cubic meters; Sevastopol - 107.58; Vinnytsia region - 92.98; Volyn 96.04; Dnepropetrovsk - 81.48; Donetsk - 110.56; Zhytomyr - 92.98; Zakarpattia - 61.09; Zaporizhzhya (Vesele, Melitopol, Priazovia, Yakymivka districts - 92.98), (other administrative and territorial units of the region 84.39); Ivano-Frankivsk (Bogorodchany, Verkhovyna, Dolyna, Kosiv, Nadvirna, Rozhnyativ districts - 145.42), (other administrative and territorial units of the region - 81,48); Kyiv (Bila Tserkva, Borodyanka, Brovary, Vasylkiv, Ivankiv, Kagarlyk, Kyiv-Svyatoshin, Makariv, Myronivka, Obukhiv, Polissia districts - 67.59), (other administrative and territorial units of the region - 79.75); Kirovograd - 107.58; Lviv - 84.39; Luhansk - 122.13; Mykolaiv - 122.13; Odesa - 101.8; Poltava (Velyka Bahachka, Hadiach, Zinkiv, Lokhvitsia, Lubny, Myrhorod, Novi Sanzhary, Reshetylivka, Khorol, Shishaky districts 62.9), (other administrative and territorial units of the region - 70.1); Rivne (Volodymyrets, Zdolbuniv, Kostopil, Rivne, Sarny, and Ostroh districts - 75.03), (other administrative and territorial units of the region - 87.16); Sumy (Hlukhiv, Sumy, Romny, Shostka districts - 70.1), (other administrative and territorial units of the region 79.83); Ternopil - 113.45; Kharkiv - 87.21; Kherson 87.21; Khmelnytsk (Derazhnya, Krasyliv, Letychiv, Starokostiantyniv, Khmelnytsk, Polonne, Shepetivka districts - 72.74), (other administrative and territorial units of the region - 110.56); Cherkasy - 62.9); Chernivtsi 101.8; Chernihiv - (Gorodnya, Koriukivka, Ichnya, Sosnytia, Snovsk, Talalaivka districts - 87.21), (other administrative and territorial units of the region - 68.19); Kyiv - 86.9.

Rental rates for special use of water, which is included exclusively in beverages as of $[11-12 ; 14]$ :

1) January 1,2015 , when using surface water amounted to $33.85 \mathrm{UAH}$ / cubic meters, when using groundwater 39.48 UAH / cubic meter;

2) January 1, 2016, when using surface water amounted to $42.82 \mathrm{UAH}$ / cubic meters, when using groundwater from 49.94 to $55.13 \mathrm{UAH} /$ cubic meter;

1) January 1,2019 , when using surface water amounted to 55.21 UAH / cubic meters, when using groundwater 64.39 UAH/ cubic meter.

The Law of Ukraine "On Amendments to the Tax Code of Ukraine on Improving the Investment Climate in Ukraine" of December 21, 2016 No. 1797-VIII, in particular, amended Article 255 of the Tax Code of Ukraine on the exclusion of secondary water users from the list of payers from January 1,2018. That is, business entities that receive water on the basis of agreements with water utilities or other entities will not pay water rent after 2018, regardless of whether or not they use water in their activities. By this time, business entities did not pay rent for water, which is used to meet "drinking" and sanitary needs.

The subject of taxation is the actual volume of water used by water users, taking into account losses in water supply systems, as well as a special use of water without its withdrawal from water bodies. It is about the use of water for the needs of fish farming, hydropower and water transport [14]. Along with the rental rates for special use of water, the special rates are used to water for the needs of hydropower, water transport, fish farming, housing and communal services, for the special use of water, which is exclusively included in the drinks, for the use of water by thermal power plants with a direct-flow water supply system, for the special use of mine, quarry and drainage water $[3-4 ; 6 ; 12]$. It should also be noted that the rate of 




18,0



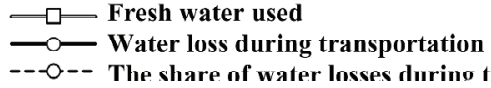

Fig. 11. Dynamics of "fresh" water use and water loss during transportation

Reference: $[9-11 ; 15]$.

charge (rent) for the use of water for the needs of housing and communal services was applied with 0.3 coefficient.

The initiative of the State Agency of Water Resources of Ukraine on the distribution of the fee for special use of water from national water bodies between the state and local budgets in the proportion of 50 to 50 can be considered a breakthrough step in the distribution of rent (fig. 6). This, on the one hand, has expanded the tax base of local budgets, and on the other - has increased the interest of the local government in ensuring the adequate and transparent withdrawal of water rent, based on the volume of water resources involved in an economic turnover.

It is the fundamental changes in the inter-budgetary distribution of water rent that have had a decisive impact on the dynamics of revenues of rent for special use of water in the state budget of Ukraine. The actual rent for the special use of water showed an upward trend from 2007 to 2010 (fig. 7).

Thus, the actual volume of water rent revenues to the state budget of Ukraine increased in 2010 compared to 2007 by UAH 370.6 million, compared to 2009 - by 169 million $\mathrm{UAH}$ due to the fact that the rent for special use of water since 2011 has begun to be distributed equally between the state and local budgets; between 2011 and 2018 the volume of water rent revenues has not reached the level of 2010. In particular, in 2013, the volume of water rent revenues to the State budget of Ukraine increased by UAH $225.9 \mathrm{mln}$ UAH compared to 2007 and by $105.4 \mathrm{mln}$ UAH compared to 2010. A similar trend also occurs in the revenues of rent for special use of water in the state budget of Ukraine in comparable prices of 2006. Prior to changes in the distribution of rent for special use of water, since 2011, the share of water rent received by the state budget of Ukraine, in the total revenues of water rent in the consolidated budget of Ukraine amounted to $98.6-98.7 \%$ between 2007 and 2010 .

Accordingly, the change in the distribution of water rent has affected the revenues of this payment to local budgets since 2011. If between 2007 and 2010 actual water rents to local budgets ranged from 6.8 to 12.2 million UAH and revenues in comparative prices of 2006 were from 5.4 to 5.9 million UAH, then starting from 2011 and ending in 2018, actual water rents to local budgets have already ranged from 554.2 to 799.7 million UAH, and compared to prices of 2006 they have ranged from 111.4 to 312.2 million UAH (fig. 8).
Despite the fact that for the period from 1999 to 2018 there was a decrease in the volume of water intake from natural water bodies in the dynamics of revenues of rent for special water use in the consolidated budget of Ukraine, there was an upward trend up to 2007. If in 1999 the volume of water intake from natural water bodies amounted to 19748 million cubic meters, in 2004 it was 14690 million cubic meters, in 2008 - 15729 million cubic meters, in 2015 - 9699 million cubic meters. That is, in 2015 compared to 1999 , the intake volume decreased by 10049 million cubic meters, compared with 2008 - by 6030 million cubic meters; a significant decrease in the volume of water intake from natural water bodies between 2014 and 2018 is due to the neglect of intake volumes on the annexed and occupied territories of Ukraine.

Instead, in 2013, the amount of rental fee for special use of water to the consolidated budget of Ukraine increased by 11 times, compared to 2008 - by 2.56 times. Growth by times takes place only in the dynamics of the actual (nominal) income water rent in the consolidated budget of Ukraine through indexing standard rates (rent rates) due to the inflation processes, the growth was not so intense in the dynamics of receipts of the water rent in comparable prices of 1998 (fig. 9).

Water rent revenue has increased in the consolidated budget of Ukraine by two times in 2013, compared with 1999 and by only 92 million UAH compared with 2008. Comparing the growth rates for the period from 1999 to 2018 , the actual value of water rent and water rent in comparable prices of 1998, it is concluded that the growth of revenues was due to the quantitative factor (mechanical growth of payment standards due to their indexation), and not due to qualitative changes in the identification of the real basis for water rent charge.

One of the instruments to promote the sustainable and rational use of water and simultaneously a regulator of the formation of the water rent and water "anti-rent" (in case of pollution by the wastewater of water bodies) is an environmental tax for the discharge of pollutants directly into water bodies. There is a general upward trend in the dynamics of the presented (paid) environmental tax for discharges of pollutants directly into water bodies from 2003 to 2018 (fig. 10). In particular, in 2010, the amount of the presented environmental tax on the discharges of pollutants 
ЕКОНОМІЧНА НАУКА



Fig. 12. Dynamics of costs for wastewater treatment, payments for the use of water resources, which were received in the consolidated budget and costs for water supply and disposal services

Reference: [9-11; 15].

directly into the water bodies amounted to 94 million UAH, which is 3.24 times more than the corresponding figure in 2003 and by 24 million UAH more than in 2006.

This correlates with the dynamics of the volumes of polluted wastewater. Thus, in 2007, the amount of contaminated wastewater amounted to 3854 million cubic meters, which is 906 million cubic meters less than in 2003. The decrease in the volume of contaminated wastewater discharge (by 2080 million cubic meters) in 2009 compared to 2007 is due to the decline in production in watercontaining industries resulting from the financial and economic recession of 2008. In 2010-2013, the volume of contaminated wastewater ranged from 1521 to 1744 million cubic meters. In 2014-2015 there was a significant decrease in the volume of contaminated wastewater discharge compared to 2013, and in 2017-2018, there was a tendency to the growth of the corresponding share.

This is due to the fact that traditionally significant volumes of contaminated wastewater discharge take place in the territories that are currently occupied. The amount of paid (presented) environmental tax for discharges of pollutants directly into water bodies in comparable prices of 2002 in 2003-2015 ranged from 12 to 41 million UAH. This scanty amount due to the physical volume of polluted wastewater discharged which is associated with low environmental tax rates for discharges of pollutants directly into water bodies doesn't stimulate the vast majority of water users to reduce polluted water discharge.

Due to the significant removal of polluted wastewater and, consequently, the entry of pollutants directly into the water bodies, the water rent received by water users is reduced due to the deterioration of water quality. At the same time the value of water "antirent" increases. The water "antirent" will decrease with the improvement of the mechanism of calculation and collection of environmental tax for discharges of pollutants directly into water bodies, which will force water users to reduce the volume of discharges of contaminated wastewater through the introduction of circulating water supply systems and modern treatment facilities.

Rent for special use of water, especially for large water users and for the needs of housing and communal services should stimulate the reduction of water losses during transportation through the modernization of water supply networks. Thus, the current level of the rental rate is not a significant incentive to reduce the loss of "fresh" water during transportation. During the period from 2011 to 2017, the volume of water losses during transportation ranged from 1139 to 2477 million cubic meters, which respectively amounts from 11.7 to $16.4 \%$ of the total use of "fresh" water (fig. 11).

The volume of use of "fresh" water decreased by $3233 \mathrm{mi}-$ llion cubic meters in 2017 compared to 2010 , and by $3412 \mathrm{mi}-$ llion cubic meters -compared to 2008. There was a slight decrease in the percentage of water losses during transportation in 2014 and 2015 compared to 2012 and 2013. This is due to the fact that the volume of water losses during transportation in the part of the territory of the old industrial regions that were occupied during this period and where the water supply networks are characterized by a high level of physical deterioration is not taken into account. Therefore the water losses during transportation here are somewhat higher than in other regions.

The current fiscal-stimulation mechanism of sustainable water use in Ukraine provides a reference of only environmental tax for discharges of pollutants directly into 


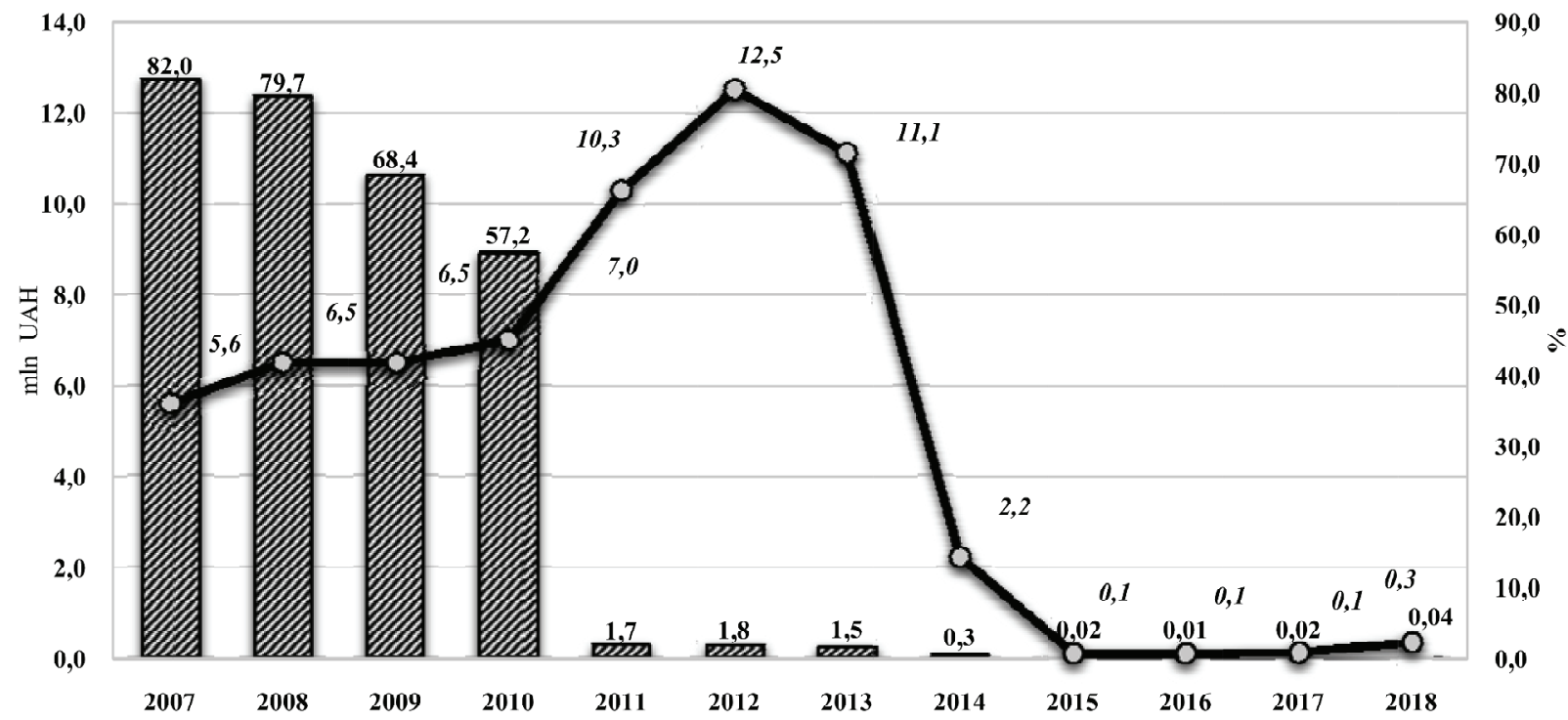

wow Rental fee for special use of water from water bodies of local importance in the total amount of rental fee for special water use to local budgets (right axis)

Kental fee for special use of water of local water bodies (left axis)

Fig. 13. Dynamics of rent payment for special use of water from water bodies of local importance

Reference: [9-11; 15].

water bodies (when this fiscal payment was sent to special funds - environmental protection funds) to the financing of wastewater treatment projects. Rent for special use of water comes to the general base of the relevant budgets and dissolves in the total amount of revenues and is completely unrelated to the priorities of financing of capital investments and running costs for wastewater treatment $[3 ; 6]$.

During the period from 2000 to 2018 , the cost of wastewater treatment as a whole was growing from year to year. Wastewater treatment costs include capital investment and operating costs. Even if we sum up the total amount of payments for the use of water resources (rent for special use of water and environmental tax for discharges of pollutants directly into water bodies) and the cost of water supply and disposal services, they only cover $20-30 \%$ of the total cost of wastewater treatment, which were financed in Ukraine by enterprises, institutions and organizations from all possible sources (own funds, funds of the state and local budgets and other sources) (fig. 12).

Besides, this suggests that part of the cost of water resources which is withdrawn in favor of the state and territorial communities in the form of rent for special water use, does not fully contribute to the formation of funds for the reproduction and protection of water resource potential and therefore the rental rates for certain categories of water users should be revised toward the increase. This also applies to the rates of environmental tax for discharges of pollutants directly into water bodies.

During the period from 2007 to 2018, there were some changes in the identification of the base for charging rent for special use of water, which are associated with the allocation of volumes of the special use of water from water bodies of local importance. Starting in 2007 and ending in 2012, the upward trend was observed in the dynamics of rent payments for the special water use of water bodies of local importance to local budgets. The amount of rent payment for special use of water bodies of local importance increased by 6.9 million UAH in 2012 compared with 2007 , and by 5.5 million UAH compared with 2010 (fig. 13).

Revenues from the specified component for special water use decreased significantly in the period from 2014 to 2018 (in 2014 - by 2.2 million UAH, in 2015-2016 and 2017-2018 - by approximately 0.1 million UAH). In 2007-2010, the share of revenues of rent for special use of water of local importance in the total amount of revenues of rent for special use of water in local budgets ranged from 57.38 to $82.35 \%$. The share of this component of the rent in local budgets has ranged from 0.1 to $1.73 \%$ since 2011 (the distribution of the rent for special use of water between the state and local budgets is 50 to 50 since this year).

\section{SUMMARY}

The institutionalized territorial and basin principle of charging rent for special use of water requires a significant transformation in the direction of deepening the differentiation of standards of payment for special use of surface and ground water. This will make it possible to expand the base of charging rent for special use of water, as well as to equalize the conditions of water use in different regions of Ukraine. Best international practices should be used to diversify the instruments of rent regulation of sustainable water use, which will increase the level of coverage of fiscal payments for the processes of economic development of water-resource potential and stabilize the development of the natural and resource sector of the national economy.

\section{$\Lambda$ ітература:}

1. Голян В. Водна рента: чи є резерви зростання надходжень до Зведеного бюджету України. URL: http:// ua-ekonomist.com/16250-vodna-renta-chi-ye-rezervizrostannya-nadhodzhen-do-zvedenogo-byudzhetuukrayini.html.

2. Голян В.А., Бардась В.М.,Аовга I.А. Фіскальне регулювання використання та охорони водних ресурсів в Україні: основні тенденції, територіальна асиметрія, напрями конвергенції з передовим досвідом. Інвестиції: практика та досвід. 2015. № 23. С. 13-22.

3. Аанилишин Б.М. Наукові нариси з економіки природокористування: монографія / Б.М. Аанилишин. К.: РВПС України НАН України, 2008. 280 с.

4. Огонь Ц.Г. Ефективність оподаткування та проблеми раціонального використання й відновлення водних ресурсів. Фінанси України. 2010. № 1. С. $16-$ 28.

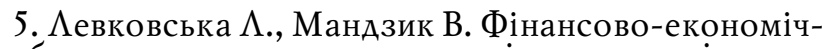
не забезпечення проектного управління територіальним водно-господарським комплексом. Вісник ХНАУ. Серія: Економічні науки. 2016. № 2. С. 323-334. 
6. Хвесик М., Голян В., Бардась В. Формування нової моделі фіскального регулювання природокористування: інституціональні передумови, методологічне забезпечення та практичні рекомендації. Економіст. 2013. № 9 . C. $4-13$.


гіональні характеристики показників вартості водних ресурсів України. Фінанси України. 2015. № 9. С. 110124.

8. Офіційний сайт Офісу з фінансового та економічного аналізу у Верховній Раді України. URL: https:// feao.org.ua

9. Офіційний сайт Аержавної служби статистики України. URL: http://www.ukrstat.gov.ua

10. Офіційний сайт Аержавної казначейської служби України. URL: https://www.treasury.gov.ua

11. Офіційний сайт Аержавного агентства водних ресурсів України. URL: https://www.davr.gov.ua

12. Офіційний сайт Аержавної фіскальної служби України. URL: http://sfs.gov.ua

13. Петруха С.Ао питання природи та ідентифікації структурних зрушень в економіці: методологічний аспект / С. Петруха, Н. Петруха // Економіст. 2013. № 8. C. $23-26$.

14. Петруха С.В. Економіка харчової промисловості України: "перша хвиля" світової фінансово-економічної рецесії / С.В. Петруха, Н.M. Петруха // Економіка харчової промисловості. 2013. № 2. С. 5-16.

15. Петруха С.В. Ринкова трансформація аграрного сектору економіки України: від аграрної кризи до формування підвалин реалізації глобальних цілей сталого розвитку / С.В. Петруха // Агросвіт. 2017. № 18. С. 3-46.

16. Голян В. Земельна реформа в Україні: пріоритети та інституційні передумови поглиблення / В. Голян, С. Петруха, А. Забловський // Економіст. - 2017. № 8. C. $8-17$.

\section{References:}

1. Holian V. (2017), "Water rent: are there any growth reserves for the Consolidated Budget of Ukraine?", available at: http://ua-ekonomist.com/16250-vodna-renta-chi-yerezervi-zrostannya-nadhodzhen-do-zvedenogo-byudzhetuukrayini.html (Accessed 10 Aug 2019).

2. Holian, V.A. Bardas', V.M. and Dovha, I.A. (2015), "Fiscal regulation of water resources use and protection in Ukraine: key trends, territorial asymmetry, areas of convergence with best practices", Investytsii: praktyka ta dosvid, vol. 23, pp. 13-22.

3. Danylyshyn, B.M. (2008), Naukovi narysy z ekonomiky pryrodokorystuvannia [Scientific Essays on the Economics of Environmental Management], RVPS Ukrainy NAN Ukrainy, Kyiv, Ukraine.

4. Ohon', Ts.H. (2010), "Efficiency of taxation and problems of rational use and restoration of water resources", Finansy Ukrainy, vol. 1, pp. 16-28.

5. Levkovs'ka, L. and Mandzyk, V. (2016), "Financial and economic support of the project management of the territorial water-economic complex", Visnyk KhNAU. Seriia : Ekonomichni nauky, vol. 2, pp. 323-334.

6. Khvesyk, M. Holian, V. and Bardas', V. (2013), "Formation of a new model of fiscal regulation of environmental management: institutional prerequisites, methodological support and practical recommendations", Ekonomist, vol. 9, pp. 4-13.

7. Khvesyk, M.A. Levkovs'ka, L.V. and Sunduk, A.M. (2015), "Regional characteristics of indicators of the value of water resources of Ukraine", Finansy Ukrainy, vol. 9, pp. $110-124$.

8. Financial and Economic Analysis Office in the VRU (2019), available at: https:// feao.org.ua (Accessed 10 Aug 2019).

9. State Statistics Committee of Ukraine (2013), Statistical information, available at: http://www.ukrstat.gov.ua (Accessed 10 Aug 2019).
10. The State Treasury Service of Ukraine (2019), available at: https://www.treasury.gov.ua (Accessed 10 Aug 2019).

11. State Water Resources Agency of Ukraine (2019), available at: https://www.davr.gov.ua (Accessed 10 Aug 2019).

12. State Fiscal Service of Ukraine (2019), available at: http:// sfs.gov.ua (Accessed 10 Aug 2019).

13. Petrukha, S. (2013), "On the question of the nature and identification of structural changes in the economy: a methodological aspect", Ekonomist, vol. 8, pp. 23-26.

14. Petrukha, S.V. (2013), "Ukraine's food industry: the "first wave" of the global financial and economic recession", Ekonomika kharchovoi promyslovosti, vol. 2, pp. 5-16.

15. Petrukha, S.V. (2017), "Market transformation of the agrarian sector of the Ukrainian economy", Ahrosvit, vol. 18, pp. 3-46.

16. Holian, V. (2017), "Land reform in Ukraine: priorities and institutional prerequisites for deepening", Ekonomist, vol. 8, pp. 8-17.

Стаття надійлла до редакиї 21.08.2019 p.



www. investplan.com.ua

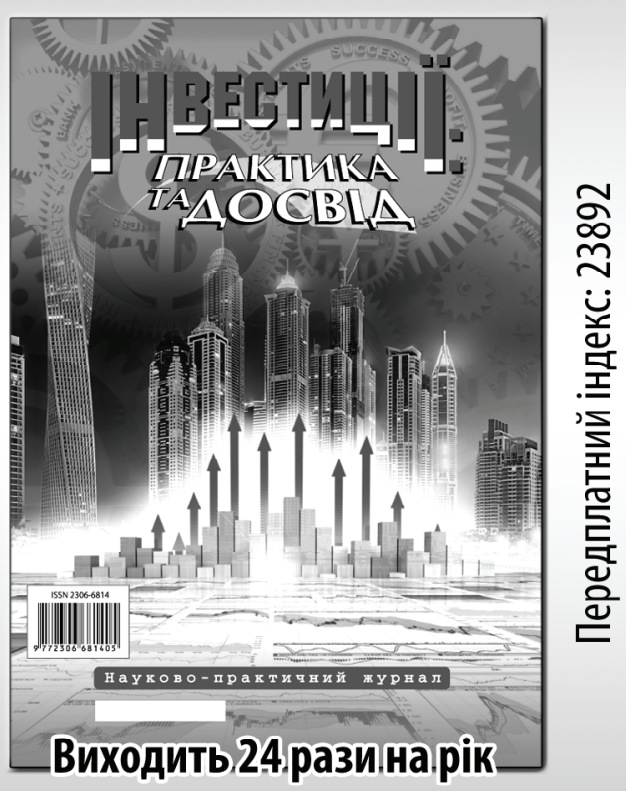

Видання включено до переліку наукових фахових видань України 3 ЕКОНОМІКИ та ДЕРЖАВНОГО УПРАВЛІННЯ 